\title{
Phenotypic plasticity of Neonotonia wightii and Pueraria phaseoloides grown under different light intensities
}

\author{
LEONARDO D.T. SANTOS ${ }^{1}$, LEANDRO R. DA CRUZ ${ }^{1}$, SAMUEL A. DOS SANTOS ${ }^{1}$, \\ BRUNO F. SANT'ANNA-SANTOS ${ }^{1}$, IZABELA T. DOS SANTOS ${ }^{1}$, ARIANE M. DE OLIVEIRA ${ }^{1}$, \\ RODRIGO E. BARROS ${ }^{1}$, MÁRCIA V. SANTOS ${ }^{2}$ and RODRIGO M. FARIA ${ }^{1}$ \\ ${ }^{1}$ Universidade Federal de Minas Gerais, Departamento de Biologia e Manejo de Plantas Daninhas, \\ Avenida Universitária, 1000, Bairro Universitário, 39404-547 Montes Claros, MG, Brasil \\ ${ }^{2}$ Universidade Federal dos Vales do Jequitinhonha e Mucuri, Departamento de Zootecnia, \\ Rodovia BR 367, Km 583, nº 5000, 39100-000, Diamantina, MG, Brasil
}

Manuscript received on January 25, 2014; accepted for publication on July 29, 2014

\begin{abstract}
Plants have the ability to undergo morphophysiological changes based on availability of light. The present study evaluated biomass accumulation, leaf morphoanatomy and physiology of Neonotonia wightii and Pueraria phaseoloides grown in full sunlight, as well as in 30\% and 50\% shade. Two assays were performed, one for each species, using a randomized block design with 10 replicates. A higher accumulation of fresh mass in the shoot of the plants was observed for both species under cultivation in $50 \%$ shade, while no differences were detected between the full sunlight and 30\% shade. $N$. wightii and P. phaseoloides showed increase in area and reduction in thickness leaf when cultivated in $50 \%$ shade. There were no changes in photosynthetic rate, stomatal conductance, water use efficiency and evapotranspiration of $P$. phaseoloides plants because growth environment. However, the shade treatments caused alterations in physiological parameters of $N$. wightii. In both species, structural changes in the mesophyll occurred depending on the availability of light; however, the amount of leaf blade tissue remained unaltered. Despite the influence of light intensity variation on the morphophysiological plasticity of $N$. wightii and $P$. phaseoloides, no effects on biomass accumulation were observed in response to light.
\end{abstract}

Key words: adaptation, Fabaceae, morphophysiology, shading.

\section{INTRODUCTION}

Growing plants under low light intensity usually results in morphoanatomic alterations, including increases in leaf area and stomatal density, decrease the amount of epicuticular waxes, and leaf blade and cuticle thickness reduction (Gondim et al. 2008, Lima Jr. et al. 2006).

Physiologically, reductions in the photosynthetic rate, stomatal conductance, and evapotranspiration

Correspondence to: Leonardo David Tuffi Santos

E-mail:1tuffi@ufmg.br occur in environments with low light intensities (Lima Jr. 2006, Morais et al. 2003). Nevertheless, plants occasionally do not show these variations or may even display distinct physiological behaviors based on light intensity (Da Matta et al. 2001, Lima Jr. et al. 2006). The phenotypic plasticity of a species and its interactions with abiotic factors in the environment could be associated with its response to light.

Neonotonia wightii (Graham ex Wight and Arn.) J. A. Lackey (perennial soybean) and Pueraria 
phaseoloides (Roxb.) Benth (pueraria) both belong to the family Fabaceae and are frequently used as fodder legumes and green manure. The cultivation of $N$. wightii and $P$. phaseoloides is beneficial to agrosystem activities, including soil conservation, weed management and increases in organic matter and nitrogen contents in the soil.

Difficulties in the management of $N$. wightii, as well as high rates of weed infestation during the cultivation of this species, have been reported in sugarcane producing areas of Brazil (Kuva et al. 2007). N. wightii is known to be tolerant to glyphosate, which may be due to its low rate of absorption and the limited translocation of this product (Hipolito et al. 2011). The management of this species is mainly based on the knowledge of its growth and development (Campos et al. 2012), which requires further studies under different environmental conditions.

P. phaseoloides and N. wightii are characterized by high levels of biomass production, robust growth, and significant potential for use as fodder plants and green manure. Thus, these plants have a strong capacity for competing with other crops (Banful et al. 2007).

The study the ecophysiological adaptations of these species in limited-light systems, such as agroforestry systems, is of great importance to tropical agroecosystems. In this context, the present study evaluated biomass accumulation, leaf morphoanatomy, physiology, and nodulation of $N$. wightii and $P$. phaseoloides grown under different light intensities.

\section{MATERIALS AND METHODS}

The field experiment was conducted from August to November of 2012 in the municipality of Montes Claros - Minas Gerais (MG), which is located at a longitude of $43^{\circ} 51^{\prime} 53^{\prime \prime} \mathrm{W}$, latitude of $16^{\circ} 44^{\prime} 13^{\prime \prime}$ $\mathrm{S}$, and at an altitude of $650 \mathrm{~m}$, from August to November of 2012. The climate of the region is a tropical savanna $(A w)$, characterized by warm, rainy summers and dry winters. Climate data during the study period are shown in Figure 1.

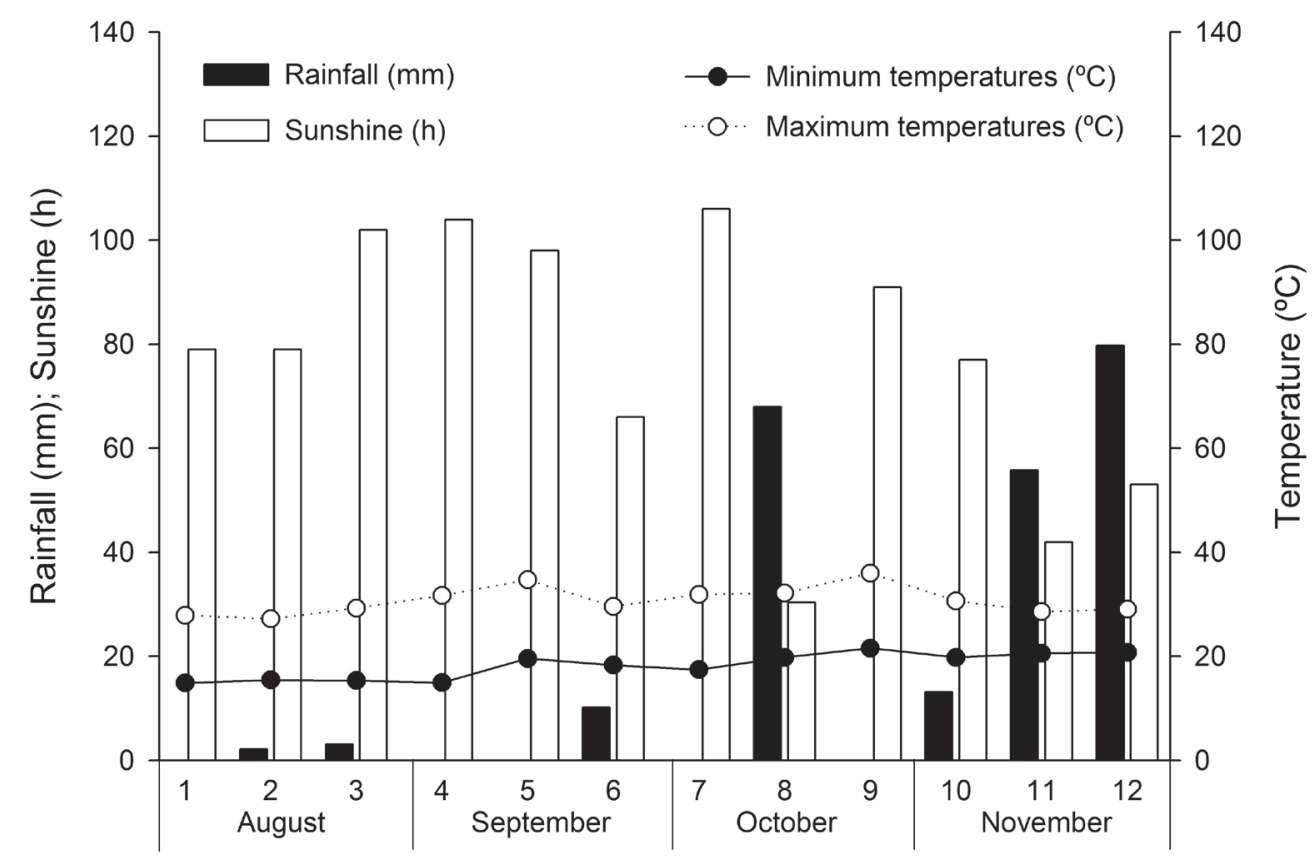

Fig 1 - Rainfall (mm) and sunshine (h) accumulation for the every ten days and mean maximum and minimum temperatures $\left({ }^{\circ} \mathrm{C}\right)$ during the field experiment. 
Seeds of $N$. wightii and P. phaseoloides were sown in parallel grooves at a depth of $2.0 \mathrm{~cm}$ in 12-L pots, which had previously been filled with soil:sand:cured bovine manure substrate at a ratio of $3: 1: 1$ and $10 \mathrm{~kg}$ of NPK at a ratio of $4: 30: 10$ for each $1.0 \mathrm{~m}^{3}$ of substrate. Physical and chemical analyses of the substrate showed the following characteristics: $\mathrm{pH}=6.2 ; \mathrm{P}=490 \mathrm{mg} \mathrm{kg}^{-1} ; \mathrm{K}=159$ $\mathrm{mg} \mathrm{kg}{ }^{-1} ; \mathrm{Ca}=7.00 \mathrm{cmolc} \mathrm{dm}^{-3} ; \mathrm{Mg}=2.00 \mathrm{cmolc}$ $\mathrm{dm}^{-3} ; \mathrm{Al}=0.00 \mathrm{cmolc} \mathrm{dm}^{-3} ; \mathrm{H}+\mathrm{Al}=1.32$ cmolc $\mathrm{dm}^{-3} ; \mathrm{SB}=9.41 \mathrm{cmolc} \mathrm{dm}^{-3} ; \mathrm{T}=9.41 \mathrm{cmolc} \mathrm{dm}^{-3}$; organic matter $=6.67 \mathrm{dag} \mathrm{kg}^{-1}$; grit $=41.70 \mathrm{dag} \mathrm{kg}^{-1}$; fine sand $=18.30 \mathrm{dag}^{-1}$; silt $=22.00 \mathrm{dag} \mathrm{kg}^{-1}$; and clay $=18.00 \mathrm{dag} \mathrm{kg}^{-1}$. When the plants reached the stage of two fully expanded leaves, pruning was performed, leaving three vigorous plants in each pot spaced equidistantly from each other.

The trials were conducted using a completely randomized design with 10 replicates under three growing environments: full sunlight, 30\% shade, and $50 \%$ shade. Each experimental plot comprised one pot, containing three $N$. wightii plants in trial 1 and three $P$. phaseoloides plants in trial 2.

Black polypropylene shade cloths were used to obtain the $30 \%$ and $50 \%$ shade environments. The plants were maintained in their treatment environments from the sowing step onward. Although both species had stoloniferous growth, the plants in the pots were maintained only with taproots to control their development. All plants were supported with bamboo sticks of approximately $1 \mathrm{~cm}$ diameter, and whenever necessary, weeds were manually pulled out of the pots. Irrigation was provided two or three times daily to maintain soil moisture in simulation of field conditions.

At 65 days after sowing (DAS), 10 fully expanded leaves were collected from the intermediate shoots of the plants (as replicates) to assess the leaf area (LA) of each species in each environment. The leaves were imaged using a digital camera, and image analysis was performed using the software Image-Pro Plus, version 4.1, for Windows ${ }^{\circledR}$ (Media Cybernetics,
Silver Spring, MD, USA). The blade area was calculated for each leaf observed in the image.

With regard to the anatomical studies, two samples were collected from the medial area of the fully expanded leaves from each of the 10 replicates for each environment and species. After fixation $\mathrm{FAA}_{50 \%}$ solution (Johansen 1940) and dehydration in the ethylic series, the samples were placed in methaclylate. Transversal sections ( $7 \mu \mathrm{m}$ thick) were obtained using a Reichert rotary microtome and stained with toluidine blue $(\mathrm{pH}=4.0)\left(\mathrm{O}^{\prime}\right.$ Brien and McCully 1981), and the slides were mounted in Permount. The images were obtained using a light microscope (Primo Star, Zeiss) with a digital camera (AxioCam ERc5s, Zeiss). In the transversal sections we measured the thickness of the limb (TLB), palisade parenchyma (PP) and spongy parenchyma (SP), the height of the adaxial (ADE) and abaxial epidermis (ABE), as well as the intercellular space areas (SIA) and number of the chlorophyllic parechma cells (NCPC) at the leaf mid-region. Were performed 27 measures/repetitions/parameters. The Image Pro-Plus software was used.

Physiological evaluations of $N$. wightii and $P$. phaseoloides plants were conducted at 100 DAS using fully expanded leaves that were externally located in the canopies of the plants. For plants grown in the different environments, the following parameters were determined: photosynthetic rate (A), stomatal conductance (Gs), transpiration (E), leaflet temperature (TIF), and water-use efficiency (WUE). To determine leaf gaseous exchange, a portable LI-6400 analyzer (Li-Cor Inc., Nebraska, USA) was used. Measurements in specific locations were conducted between 08:00 and 11:00, always in the same block, to reduce experimental error. Minimum time, established in advance for the stabilization of measurements, was $120 \mathrm{~s}$, and maximum time for recording each measurement was $180 \mathrm{~s}$.

At 100 DAS, the shoots of the N. wightii and $P$. phaseoloides plants were pruned to determine 
total mass and dry mass. The latter was obtained after drying the plant in a forced-air oven at 60 ${ }^{\circ} \mathrm{C}$ until a constant weight was achieved. The root system was gently washed using low water pressure to remove any remnants of the substrate. The washing was performed using $0.5-\mathrm{mm}$ sieves to prevent the loss of nodules that contained nitrogen-fixing bacteria (NFB). After washing, the nodules attached to the roots, as well as those retained in the sieves, were counted and summed for each pot. Subsequently, the nodules and the roots were stored separately in paper bags, and their dry mass values were determined after drying in a forced-air oven at $60{ }^{\circ} \mathrm{C}$ until constant weights were achieved.
The data were subjected to analysis of variance (ANOVA) and, when relevant, averages were compared using Tukey's test at a significance level of 5\%.

\section{RESULTS}

Neonotonia wightii and Pueraria phaseoloides showed good plant development in the shaded environments, with higher plant masses observed in the shoots grown under $50 \%$ shade, while no differences were observed between plants maintained in full sunlight and 30\% shade (Table I). In the shaded environments, both species accumulated dry mass in their roots and shoots in an amount equivalent to the levels obtained under full sunlight conditions (Table I).

TABLE I

Biomass accumulation in the shoots and roots, as well as nodulation, of Neonotonia wightii and Pueraria phaseoloides cultivated under different light intensities.

\begin{tabular}{|c|c|c|c|c|c|}
\hline \multirow{2}{*}{ Environment } & \multicolumn{2}{|c|}{ Shoots $(\mathrm{g})$} & \multirow{2}{*}{ Root dry mass $(\mathrm{g})^{\mathrm{ns}}$} & \multicolumn{2}{|c|}{ Nodules } \\
\hline & Fresh mass & Dry mass $^{\text {ns }}$ & & Number & Dry mass $(\mathrm{g})^{\mathrm{ns}}$ \\
\hline \multicolumn{6}{|c|}{ Neonotonia wightii } \\
\hline Sunlight & $450.12^{1} \mathrm{~b}$ & 137.58 & 13.92 & $2252 \mathrm{a}$ & 4.19 \\
\hline $30 \%$ shade & $469.71 \mathrm{~b}$ & 129.47 & 15.96 & $1419 b$ & 4.52 \\
\hline $50 \%$ shade & $539.44 \mathrm{a}$ & 141.16 & 16.35 & $1340 \mathrm{~b}$ & 2.69 \\
\hline $\mathrm{CV}(\%)$ & 10.32 & 11.83 & 16.44 & 20.96 & 38.00 \\
\hline \multicolumn{6}{|c|}{ Pueraria phaseoloides } \\
\hline Sunlight & $381.04^{1} \mathrm{~b}$ & 95.16 & 10.45 & 386.50 & 4.13 \\
\hline $30 \%$ shade & $439.10 \mathrm{ab}$ & 115.89 & 9.63 & 507.33 & 6.68 \\
\hline $50 \%$ shade & $461.05 \mathrm{a}$ & 115.77 & 10.20 & 563.00 & 3.60 \\
\hline CV (\%) & 13.60 & 19.39 & 24.86 & 20.87 & 32.62 \\
\hline
\end{tabular}

For each species, means followed by the same letter in a column do not differ according to Tukey's test at $5 \%$ probability. ${ }^{\text {ns }}$ Not significant at $5 \%$ using the $\mathrm{F}$ test. $\mathrm{CV}=$ coefficient of variation. ${ }^{1}$ Mean of 10 plots.

The number of NFB nodules was the highest in $N$. wightii cultivated in full sunlight, while no difference was observed between nodule numbers in the plants cultivated in the $30 \%$ and $50 \%$ shade environments (Table I). Dry mass values of the nodules measured in $N$. wightii were statistically identical among the different cultivation environments, although lower absolute values were obtained in the $50 \%$ shade environment (Table I). For P. phaseoloides, no variations were observed in the dry mass values of the nodules among the different cultivation environments (Table I).
A stronger association between the dry biomass values of shoots and roots was observed in $N$. wightii cultivated in full sunlight (9.88) than in plants cultivated in 30\% (8.11) and 50\% (8.63) shade. However, in $P$. phaseoloides, the highest values were observed in plants cultivated in 30\% shade (12.04), followed by those in 50\% shade (11.35) and full sunlight (9.11).

The leaf blade area was the highest in $N$. wightii and $P$. phaseoloides cultivated in a $50 \%$ shade environment. The two species presented their lowest leaf areas in full sunlight (Table II). 
TABLE II

Mean area per leaf (LA) and thicknesses of the leaf blade (TLB), palisade parenchyma (PP), spongy parenchyma (SP), abaxial epidermis (ABE), and adaxial epidermis (ADE) of Neonotonia wightii and Pueraria phaseoloides cultivated under different light intensities.

\begin{tabular}{ccccccc}
\hline Environment & LA $\left(\mathrm{cm}^{2}\right)$ & TLB $(\mu \mathrm{m})$ & PP $(\mu \mathrm{m})$ & SP $(\mu \mathrm{m})$ & ABE $(\mu \mathrm{m})$ & ADE $(\mu \mathrm{m})$ \\
\hline Sunlight & $30.93 \mathrm{c}$ & $180.62 \mathrm{a}$ & $20.09 \mathrm{a}$ & $86.93 \mathrm{a}$ & $61.79 \mathrm{a}$ & $11.81 \mathrm{a}$ \\
30\% shade & $52.63 \mathrm{~b}$ & $103.64 \mathrm{~b}$ & $12.53 \mathrm{~b}$ & $50.90 \mathrm{~b}$ & $31.16 \mathrm{~b}$ & $9.05 \mathrm{~b}$ \\
$50 \%$ shade & $50.85 \mathrm{a}$ & $86.35 \mathrm{c}$ & $7.78 \mathrm{c}$ & $39.41 \mathrm{c}$ & $31.05 \mathrm{~b}$ & $8.11 \mathrm{~b}$ \\
\hline CV $(\%)$ & 13.52 & 5.83 & 11.86 & 7.76 & 10.09 & 10.06 \\
\hline \multicolumn{7}{c}{ Pueraria phaseoloides } \\
\hline Sunlight & $80.23 \mathrm{c}$ & $176.72 \mathrm{a}$ & $19.89 \mathrm{a}$ & $83.13 \mathrm{a}$ & $61.69 \mathrm{a}$ & $12.01 \mathrm{a}$ \\
30\% shade & $114.81 \mathrm{~b}$ & $105.84 \mathrm{~b}$ & $12.93 \mathrm{~b}$ & $50.90 \mathrm{~b}$ & $32.66 \mathrm{~b}$ & $9.35 \mathrm{~b}$ \\
$50 \%$ shade & $170.54 \mathrm{a}$ & $87.32 \mathrm{c}$ & $10.18 \mathrm{c}$ & $37.01 \mathrm{c}$ & $31.72 \mathrm{~b}$ & $8.41 \mathrm{~b}$ \\
\hline CV $(\%)$ & 12.26 & 6.24 & 9.79 & 7.40 & 9.32 & 9.04 \\
\hline
\end{tabular}

For each species, means followed by the same letter in a column do not differ according to Tukey's test at $5 \%$ probability. $\mathrm{CV}=$ coefficient of variation. ${ }^{1}$ Mean of 10 plots.

The plants exposed to full sunlight showed increase in the limb, palisade and spongy parenchyma, and epidermis (adaxial and abaxial) in comparison with shad environments, for both species. However, a significant alteration in the leaf blade area was not observed.

The plants exposed to sunlight showed more compact mesophyll, consisting of two rows of palisade parenchyma cells (Figure 2). However, when these plants were cultivated in the shade, a decrease in the number of chlorophyllic cells was observed, as was an increase in the proportion of mesophyllic intercellular spaces (Table III).

The photosynthetic rate of $N$. wightii cultivated in the shade was $43 \%$ higher than that of plants grown in full sunlight, and no differences were observed in plants cultivated under $30 \%$ and $50 \%$ shade (Table IV). Transpiration and stomatal conductance were $83 \%$ and $50 \%$ higher, respectively, in $N$. wightii cultivated in $30 \%$ shade than in plants cultivated under sunlight, whereas WUE was 13\% lower, although this difference was not statistically significant (Table IV). N. wightii cultivated in $50 \%$ shade showed a 39\% higher WUE than plants cultivated in full sunlight (Table IV). However, in P. phaseoloides, no differences were observed in any of the measured physiological variables among the various light intensities (Table IV).

The internal temperatures of leaflets in plants of the two species maintained at $50 \%$ shade were significantly lower than those in plants cultivated

TABLE III

Number of chlorophyllic parenchyma cells (NCPC) and percent area occupied by intercellular spaces (ISA) in Neonotonia wightii and Pueraria phaseoloides leaves cultivated under different light intensities ${ }^{1} \pm$ standard error of the mean.

\begin{tabular}{l|c|c|c|c}
\hline \multicolumn{3}{|c}{ Neonotonia wightii } & Pueraria phaseoloides \\
\hline Environment & NCPC & ISA (\%) & NCPC & ISA (\%) \\
\hline Sunlight & $71 \pm 5.22^{1}$ & $7.29 \pm 0.8$ & $71 \pm 2.89$ & $6.42 \pm 0.89$ \\
\hline $30 \%$ shade & $51 \pm 2.23$ & $18.45 \pm 1.05$ & $59 \pm 2.78$ & $15.75 \pm 1.12$ \\
\hline $50 \%$ shade & $45 \pm 1.24$ & $19.94 \pm 0.61$ & $47 \pm 2.80$ & $18.81 \pm 1.16$ \\
\hline
\end{tabular}

${ }^{1} \pm$ standard error of 10 means. 

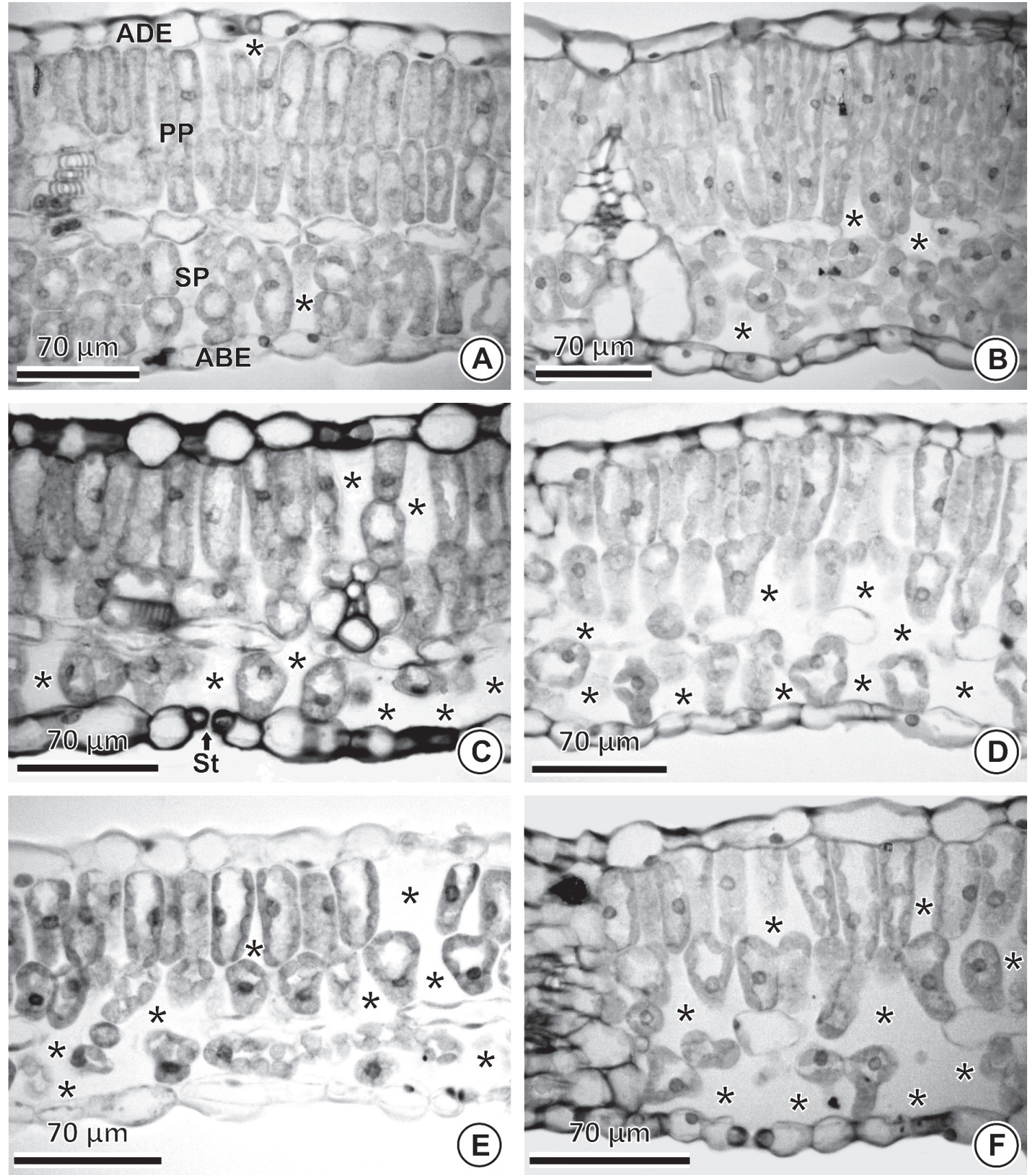

Fig 2 - Leaf structure of Neonotonia wightii (A, C, and E) and Pueraria phaseoloides (B, D, and F) cultivated under different light intensities (transverse sections observed by light microscopy). (A and B): full sunlight; (C and D): $30 \%$ shade; and (E and F): 50\% shade. Abbreviations: ADE, adaxial epidermis/surface; ABE, abaxial epidermis/surface; PP, palisade parenchyma; SP, spongy parenchyma; St, stomata; and *, intercellular spaces.

under full sunlight or $30 \%$ shade (Table IV). No differences in the temperatures of the leaflets were observed between plants grown in low shade (30\%) and full sunlight.

\section{DISCUSSION}

$N$. wightii and P. phaseoloides, two important tropical plants belonging to the family Fabaceae, presented plasticity toward different light intensity 
TABLE IV

Photosynthetic rate (A), stomatal conductance (Gs), transpiration (E), water-use efficiency (EUA), and internal temperature of leaflets (TIF) of Neonotonia wightii and Pueraria phaseoloides cultivated under different light intensities.

\begin{tabular}{cccccc}
\hline Environment & $\begin{array}{c}\mathrm{A} \\
\left(\mu \mathrm{mol} / \mathrm{m}^{2} \mathrm{~s}\right)\end{array}$ & $\begin{array}{c}\mathrm{Gs} \\
\left(\mathrm{mol} \mathrm{gases} / \mathrm{m}^{2} \mathrm{~s}^{1}\right)\end{array}$ & $\begin{array}{c}\mathrm{E} \\
\left(\mathrm{mol} \mathrm{H}_{2} \mathrm{O} / \mathrm{m}^{2} \mathrm{~s}\right)\end{array}$ & $\begin{array}{c}\text { WUE } \\
\left(\mathrm{mol} \mathrm{CO}_{2} / \mathrm{mol} \mathrm{H}_{2} \mathrm{O}\right)\end{array}$ & $\begin{array}{c}\mathrm{TIF} \\
\left({ }^{\circ} \mathrm{C}\right)\end{array}$ \\
\hline Sunlight & $9.40^{1} \mathrm{~b}$ & $0.18 \mathrm{~b}$ & $4.52 \mathrm{~b}$ & $2.34 \mathrm{~b}$ & $38.67 \mathrm{a}$ \\
$30 \%$ shade & $13.85 \mathrm{a}$ & $0.33 \mathrm{a}$ & $6.80 \mathrm{a}$ & $2.04 \mathrm{~b}$ & $38.59 \mathrm{a}$ \\
$50 \%$ shade & $12.90 \mathrm{a}$ & $0.18 \mathrm{~b}$ & $4.44 \mathrm{~b}$ & $3.26 \mathrm{a}$ & $34.25 \mathrm{~b}$ \\
\hline $\mathrm{CV}(\%)$ & 16.12 & 35.60 & 27.87 & 34.31 & 9.75 \\
\hline \multicolumn{7}{c}{ Pueraria phaseoloides ${ }^{\mathrm{ns}}$} \\
\hline Sunlight & $11.56^{1}$ & 0.31 & 7.41 & 1.66 & $39.86 \mathrm{a}$ \\
$30 \%$ shade & 11.58 & 0.27 & 6.83 & 1.70 & $39.78 \mathrm{a}$ \\
$50 \%$ shade & 12.14 & 0.29 & 6.54 & 1.86 & $37.40 \mathrm{~b}$ \\
\hline $\mathrm{CV}(\%)$ & 19.50 & 26.19 & 19.48 & 21.99 & 4.72 \\
\hline
\end{tabular}

For each species, means followed by the same letter in a column do not differ according to Tukey's test at $5 \%$ probability. ${ }^{\mathrm{ns}} \mathrm{Not}$ significant at $5 \%$ using the $\mathrm{F}$ test. $\mathrm{CV}=$ coefficient of variation. ${ }^{1}$ Mean of 10 plots.

environments, indicating an ability to accumulate the same quantities of biomass in shaded environments as in full sunlight conditions. In wooded agroecosystems, such as agroforestry systems, light restriction may influence the productivity of certain species (Cavatte et al. 2012, Chauhan 2013), however, this effect does not occur in $N$. wightii and $P$. phaseoloides. Fujita et al. (1993) observed an increase in the $P$. phaseoloides maintained under $55 \%$ shade, emphasizing the potential of this species for cultivation under restricted sunlight.

Such observations highlight the importance of using these species in silvopasture systems, as good root development under low light intensity is directly associated with persistence and good yield in pastures (Oliveira and Solto, 2003). However, adaptation to shading has its limitations (Holmgren et al. 2012, Cavatte et al.2012). Cavatte et al. (2012) found higher growth rates and carbon accumulation in plants of Coffea arabica exposed to full sunlight compared with plants exposed to intense shading (85\%).

Variations in light availability induce ecophysiological adaptation in plants, with consequent alterations in their anatomy and leaf morphophysiology.
The plasticity to climate variation observed in $N$. wightii and P. phaseoloides may be related to alterations in their morphoanatomic structure of their leaves, which are influenced by the intensity or availability of light. Despite the restriction of stoloniferous growth in the pots, limiting biomass accumulation by the plants, the physiology and anatomy of the leaves could be accurately compared. Genetic and phenotypic adaptations are commonly associated with irradiance levels (Gobbi et al. 2009). Phenotypic adaptation to climate may affect the physiological and structural behaviors of plants, resulting in changes to organ differentiation, histology, biochemistry, and morphology (Lambers et al. 1998). These alterations increase the capacity of plants to capture and use light, as reflected in this study by the increased blade area, as well as the reduced blade and palisade parenchyma thicknesses, in N. wightii and P. phaseoloides cultivated in the shade. Alterations in leaf thickness to improve light capture have previously been reported in cultivated species grown under various shade conditions (Lima Jr. et al. 2006, Morais et al. 2003, Piel et al. 2002). When exposed to high light intensities, leaf blades of different plant species develop lower leaf 
areas and greater leaf thicknesses, with increased mesophyll thicknesses and reduced intercellular spaces. Conversely, leaves grown in the shade generally regulate light and gaseous diffusion, thereby maximizing photosynthetic efficiency (Terashima et al. 2006). In the present study, the increases in the number of parenchyma cells and intercellular spaces in the leaf mesophyll enhanced the photosynthetic rate of $N$. wightii.

The increase in leaf blade area, reduction in internal temperature, and anatomic alterations observed in these organs may enhance the photosynthetic rate in $N$. wightii cultivated in shaded environments. The photosynthetic rate is largely influenced by radiation (Naves-Barbiero et al. 2000), which is often altered by shading. Plants generally have specific light needs, predominantly in the red and blue wavelengths (Messinger et al. 2006). Under unfavorable light intensities in the vegetation canopy, plants are impelled to adapt because the balance in the red and far-red wavelengths is affected by shading, thereby influencing photosynthetic efficiency (Da Matta et al. 2001).

In Croton urucurana, a pioneer species, higher photosynthetic rates have also been observed in young plants cultivated at higher levels of irradiation under 30\% shade and full sunlight (Alvarenga et al. 2003). Working with shade-tolerant and sensitive species, Ramos and Grace (1990) observed greater stomatal conductance in tolerant plants cultivated in full sunlight. Welander and Ottosson (2000) observed that transpiration rates increased with irradiation in Quercus robur. A higher photosynthetic rate, as well as increased stomatal conductance, leaf blade thickness, stomata number per area, and cell wall thickness, were observed in young plant leaves of Cupania vernalis grown in full sunlight and 30\% shade compared to those of plants grown in 50\% and 70\% shade (Lima Jr. et al. 2006). In limited light conditions, photosynthetic and growth rates are lower, which negatively affects osmotic regulation and WUE (Aranda et al. 2007).
Shading reduces air and leaf temperatures, thereby decreasing overheating (Franco and Nobel, 1989) and plant transpiration (Holmgren et al. 2012). This situation may have lowered internal temperatures in the leaflets of $N$. wightii and $P$. phaseoloides cultivated in 50\% shade.

In the present study, $N$. wightii and $P$. phaseoloides showed higher water contents when grown in a shaded environment, whereas no variations in dry mass were observed. Conditions of high shading reduce the problems associated with hydric deficit in tropical species that are intolerant to dryness and tolerant to shade (Holmgren et al. 2012), such as $N$. wightii and P. phaseoloides. This situation may favor species adapted to environments characterized by low light intensities, facilitating the acquisition of resources important to plant growth. Plants exposed to high light intensities and heat, physiologically respond through protoplasmic dehydration and increased osmotic concentrations in their tissues (Gliessman 2005).

Climate adaptation and photosynthetic rate efficiency may affect ecological relationships among plants. Symbiotic atmospheric N fixation may use up to $33 \%$ of the $\mathrm{C}$ photoassimilated by the host (Michin et al. 1981). Conversely, $\mathrm{N}_{2}$ fixation in the Leguminosae may promote higher growth and photosynthetic rates (Lüscher et al. 1998). In this symbiosis, atmospheric $\mathrm{N}_{2}$ is captured by NFB, which then increase the production of carbohydrates and the availability of carbon in the nodules, resulting in increased nodular activity; this nutrient then becomes more available for plant development (Vance and Heichel, 1991). In the present study, no correlations were observed between the numbers and biomass values of the NFB nodules and the photosynthetic rates and biomass accumulations in the plants. In addition, the cultivation environments had no significant impacts on these variables in P. phaseoloides. However, in N. wightii, the number of nodules was negatively correlated with shading, indicating the presence of plant host relations, which 
were beyond the focus of this study. The activities of the nodules and plant nitrogen contents must be further evaluated in future studies to better understand the effects of light availability on the interactions between NFB and $N$. wightii and $P$. phaseoloides.

These results confirm the adaptation of $N$. wightii and $P$. phaseoloides to environments with restricted light intensities, indicating their promising potential for use in mixed cultivation involving trees in agroforestry systems and as a common source of fodder legume or green manure. Further attention should be given to the fact that these species are aggressive and difficult to manage (Banful et al. 2007, Campos et al. 2012, Kuva et al. 2007); in addition to plasticity, these factors may lead to problems in situations where the species are considered as weeds.

\section{ACKNOWLEDGMENTS}

The authors would like to thank Celulose NipoBrasileira (CENIBRA) and the Research Support Foundation of the state of Minas Gerais (FAPEMIG) for the financial support provided for the experiments and the acquisition of a photomicroscope for the Laboratory of Anatomy and Dendrology at the ICA/ UFMG. We are also grateful to the Conselho Nacional de Desenvolvimento Científico e Tecnológico (CNPq) for the scholarship offered to the first author and to the Pró-Reitoria de Pesquisa da Universidade Federal de Minas Gerais for their assistance in the translation of this manuscript.

\section{RESUMO}

As plantas têm a capacidade de sofrer mudanças morfológicas com base na disponibilidade de luz. O presente estudo avaliou a acumulação de biomassa, morfoanatomia foliar e fisiologia de Neonotonia wightii e Pueraria phaseoloides cultivadas a pleno sol, bem como a 30 e $50 \%$ de sombra. Dois ensaios foram realizados, um para cada espécie, usando um delineamento de blocos casualizados com 10 repetições. Observou-se maior acúmulo de massa fresca na parte aérea das plantas para ambas as espécies cultivadas em
$50 \%$ de sombreamento, enquanto não foram detectadas diferenças entre pleno sol e $30 \%$ de sombreamento. $N$. wightii e P. phaseoloides mostraram aumento de área e redução da espessura foliar quando cultivadas a $50 \%$ de sombreamento. Não houve alterações na taxa fotossintética, condutância estomática, eficiência no uso da água e evapotranspiração nas plantas de P. phaseoloides em função do ambiente de cultivo. No entanto, os tratamentos sombreados causaram alterações nos parâmetros fisiológicos de $N$. wightii. Em ambas as espécies, mudanças estruturais no mesofilo ocorreram dependendo da disponibilidade de luz; no entanto, a quantidade de tecido da lâmina foliar permaneceu inalterada. Apesar da influência da variação de intensidade luminosa sobre a plasticidade morfofisiológica de N. wightii e P. phaseoloides não foram observados efeitos na acumulação de biomassa em resposta à luz.

Palavras-chave: adaptação, Fabaceae, morfofisiologia, sombreamento.

\section{REFERENCES}

Alvarenga AA, CAStro EM, Lima Jr EC AND MaGalhães MM. 2003. Effects of different light levels on the initial growth and photosynthesis of Croton urucurana Baill. In southeastern Brazil. Rev Árvore 27: 53-57.

ArANDA I, PARdos M, PuERTOLAs J, JimENEZ MD AND PARdos JA. 2007. Water-use efficiency in cork oak (Quercus suber) is modified by the interaction of water and light availabilities. Tree Physiol. 27: 671-677.

BANFUL BK, HAUSER S, OFORI K AND KUMAGA FK. 2007. Weed biomass dynamics in planted fallow systems in the humid forest zone of southern Cameroon. Agrofor Syst 71: 49-55.

Campos LhF, Mello MSC, Carvalho SJP, Nicolai M AND Christoffoleti PJ. 2012. Crescimento inicial de Merremia cissoides, Neonotonia wightii e Stizolobium aterrimum. Planta Daninha 30: 497-504.

CAVATte PC, Rodriguez-Lopez NF, Martins SCV, Mattos MS, SANGLARD LMVP AND DA MATTA FM. 2012. Functional analysis of the relative growth rate, chemical composition, construction and maintenance costs, and the payback time of Coffea arabica L. leaves in response to light and water availability. J Exp Bot 63: 3071-3082.

CHAUHAN BS. 2013. Shade reduces growth and seed production of Echinochloa colona, Echinochloa crus-galli and Echinochloa glabrescens. Crop Protection 43: 241-245.

DA MATTA FM, LOOS RA, RODRIGUES R AND BARROS RS. 2001. Actual and potential photosynthetic rates of tropical crop species. Braz J Plant Physiol 13: 24-32. 
FRANCO AC AND NOBEL PS. 1989. Effects of nurse plants on the microhabitat and growth of cacti. J Ecol 77: 870-886.

Fujita K, Matsumoto K, Ofosu-Budu GK and OGata S. 1993. Effect of shading on growth and dinitrogen fixation of kudzu and tropical pasture legumes. Soil Sci Plant Nutr 39: 43-54.

GLIESSMAN RS. 2005. Agroecologia: Processos Ecológicos em Agricultura Sustentável. Planaltina: Editora UFGRS.

Gobbi KF, Garcia R, Garcez Neto AF, Pereira OP, Ventrella MC AND Rocha GC. 2009. Características morfológicas, estruturais e produtividade do capimbraquiária e do amendoim forrageiro submetidos ao sombreamento. R Bras Zootec 38: 1645-1654.

Gondim ARO, Puiatti M, Ventrella MC AND CECON PR 2008. Plasticidade anatômica da folha de taro cultivado sob diferentes condições de sombreamento. Bragantia 67: 1037-1045.

Hipolito HC, Delgado AR, Valenzuela JAD, Heredia A, Castro MDL AND PRAdo RD. 2011. Glyphosate tolerance by Clitoria ternatea and Neonotonia wightii plants involves differential absorption and translocation of the herbicide. Plant and Soil 347: 221-230.

HOLMGREN M, GOMEZ-APARICIO L, QUERO JL AND VALLADARES F. 2012. Non-linear effects of drought under shade: reconciling physiological and ecological models in plant communities. Oecol. 169: 293-305

JOHANSEN DA. 1940. Plant microtechnique. New York: McGraw - Hill Book Co. Inc.

Kuva MA, Pitelli RA, SAlgado TP AND Alves PlCA. 2007. Fitossociologia de comunidades de plantas daninhas em agroecossistema cana-crua. Planta Daninha 25: 501-511.

LAMBers H, CHAPIM FS AND PONS TL. 1998. Plant physiological ecology. New York: Springer.

Lima Jr EC, Alvarenga AA, CASTRo EM, VieIRA CV AND BARBOSA JPRAD. 2006. Aspectos fisioanatômicos de plantas jovens de Cupania vernalis Camb. submetidas a diferentes níveis de sombreamento. Rev Árvore 30: 33-41.

LÜSCHER A, HENDREY GR AND NÖSBERGER J. 1998. Long-term responsiveness to free air $\mathrm{CO}_{2}$ enrichment of functional types, species and genotypes of permanent grasslands. Oecol 113: 37-45.
MEssinger SM, BUCKLEY TN AND MOTT KA. 2006. Evidence for involvement of photosynthetic processes in the stomatal response to $\mathrm{CO}_{2}$. Plant Physiol 140: 771-778.

MichIN FR, SUMMERFIELD RJ, HADLEY P, ROBERTS EH AND RAWSTHORNE S. 1981. Carbon and nitrogen of nodulated roots of grain legumes. Plant Cell Environ. 4: 5-26.

Morais H, MARUR CJ, CARAMORI PH, RIBEIRO AMA AND GOMES JC. 2003. Características fisiológicas e de crescimento de cafeeiro sombreado com guandu e cultivado a pleno sol. Pesq Agropec Bras 38: 1131-1137.

NAVES-BARBIERo CC, Franco AC, BUCCI SJ AND GOLdSTEIN G. 2000. Fluxo de seiva e condutância estomática de duas espécies lenhosas sempre verdes no campo sujo e cerradão. Braz J Plant Physiol 12: 119-134.

O'BRIAN PP AND MCCULLY ME. 1981. The study of plant structures: principles and selected methods. Termarcarphi Pty. Ltda, Melbourne-Australua.

OLIVEIRA FL AND SOUTO SM. 2003. Estabelecimento de leguminosas forrageiras tropicais na sombra. Pasturas Tropicales 25: 13-17.

Piel C, Frak E, Roux XL and Genty B. 2002. Effect of local irradiance on $\mathrm{CO}_{2}$ transfer of mesophyll in walnut. J Exp Bot 53: 2423-2430.

Procópio SO, Santos JB, Silva AA, Martinez CA AND WERLANG RC. 2004. Características fisiológicas das culturas de soja e feijão e de três espécies de plantas daninhas. Planta Daninha 22: 211-216.

RAMOS J AND GRACE J. 1990. The effetcs of shade on the gas exchange of seedlings of four tropical trees from México. Funct Ecol 4: 667-677.

TERASHIMA I, HANBA YT, TAZOE Y, Vyas P AND YANO S. 2006. Irradiance and phenotype: comparative eco-development of sun and shade leaves in relation to photosynthetic $\mathrm{CO}_{2}$ diffusion. J Exp Bot 57: 343-354.

VANCE CP AND HeIChel GH. 1991. Carbon in $\mathrm{N}_{2}$ fixation: limitation or exquisite adaptation. Annu Rev Plant Biol 42: 373-392

WELANDER NT AND OTTOSSON B. 2000. The influence of low light, drought and fertilization on transpiration and growth in young seedlings of Quercus robur L. For Ecol Manage 127: $139-151$. 